\title{
„Time to talk“ aneb Čas mluvit o tom, komu patří angličtina v české učebnici ${ }^{1}$
}

\author{
Jana Kubrická \\ Masarykova Univerzita, Centrum jazykového vzdělávání
}

Redakci zasláno 15. 9. 2014 / upravená verze obdržena 12. 1. 2015 / k uveřejnění přijato 20. 1.2015

\begin{abstract}
Abstrakt: $\mathrm{V}$ tomto příspěvku se věnujeme identitám postav zobrazeným $\mathrm{v}$ české učebnici anglického jazyka Time to talk. Hlavním cílem studie je popsat jak různé aspekty identit postav, tak způsoby omezování možností interpretace kulturních sdělení v textech a úlohách. V první části textu představujeme koncept identity v oblasti cizích jazyků a výzkumy, které jsou na něm založeny. Pomocí obsahové analýzy, kritické analýzy diskurzu a konceptu uzavřených a otevřených textů se v empirické části textu pokoušíme odhalit, jakou představu společenství mluvčích cílového jazyka autoři učebnice vytváří. V analýze textů, ilustrací a úloh dokládáme, že učebnice reflektuje současný interkulturní diskurz, ve kterém jsou prezentována a konfrontována různá kulturní prostředí, zároveň však v textech poukazujeme na dominantní roli britské kultury a autoritu britských rodilých mluvčích. Zobrazené postavy patří k etnické majoritě, jsou často genderově stereotypní a mají střední až vyšší sociokulturní status. V učebnici je však patrný i vliv tzv. diskurzu kulturní inkorporace, kde prostor získávají dříve opomíjené sociální skupiny.
\end{abstract}

Klíčová slova: učebnice cizích jazyků, identita, rodilý mluvčí, multikulturní výchova, kritická analýza diskurzu, otevřený a uzavřený text

V tomto článku vycházíme z tradice kritické pedagogiky, aplikované lingvistiky a kritické analýzy diskurzu, kde na výuku cizích jazyků již není nahlíženo jako na doménu, která by byla hodnotově neutrální a rovnostářská. Osvojování jazyka naopak vidíme jako proces, který je ideologický, plný konfliktů spojených s identitou a determinovaný tř́́dou, rasou a ekonomickým statusem mluvčího. Často se uvádí, že výuka cizích jazyků je komplexní sociální praxe, která svým záběrem přesahuje pouhé osvojování si gramatických jevů, lexika, výslovnosti a syntaxe cílového jazyka (Lee, 2011, s. 47), zejména proto, že vyučující cizích jazyků se pohybují na pomezí dvou kultur - kultury zemí

1 Vznik studie byl podpořen z projektu Kurikulum základní školy: metodologické př́stupy a empirická zjištění (MUNI/A/0813/2013). 
cílového jazyka a tzv. zdrojové kultury (source culture) žáků. Tento prostor bývá v literatuře označován jako třetí prostor (third place) a představuje dimenzi, ve které se obě kultury potkávají a konfrontují (např̀ ve třídě). $V$ tomto prostoru při poznávání a porovnávání kultur mohou žáci rozvíjet či rozšiřovat své identity, když dostávají příležitost rozehrávat role a chování mluvčích cílového jazyka, současně však v těchto situacích rezonují diskurzní praktiky osvojené (vědomě či nevědomě) během dřivější socializace (Kramsch, 1993, s. 48). Tento typ socializace, kde se žáci setkávají s multikulturním prostředím a v ideálním případě přehodnocují nebo zavrhují myšlenky a schémata osvojená během primární a sekundární socializace, chápe Byram (1990) jako součást tzv. terciální socializace, která bývá zkoumána jako skryté kurikulum a v jejímž rámci se pohybujeme i v předkládaném textu.

Sociální a osobnostní dimenze výuky anglického jazyka včetně otázek socializace si získává stále větší pozornost (srov. Prabhu, 1992). Tento jev zřejmě souvisí s faktem, že se z angličtiny stává světová lingua franca, diverzifikuje se a je používána v nových kontextech (Warschauer, 2000). Kramschová (2014, s. 296) konstatuje, že svět se v souvislosti s globalizací, rozvojem internetu a následnou dostupností autentických cizojazyčných materiálů změnil natolik, že učitelé jazyků váhají nad tím, co vlastně mají své žáky učit a pro jaké reálné životní a světové situace by je měli připravit. Vyučující angličtiny také až do nedávna spoléhali na stabilní syntax a lexikon anglického jazyka tak, jak je uvádějí slovníky a učebnice a společně s tím vyznávali autoritu abstraktního rodilého mluvčího (Kramsch, 2014, s. 298). Vztah mezi tzv. nerodilým mluvčím a rodilým mluvčím měl asymetrický charakter a stal se terčem kritiky jak kvůli svému ideologickému obsahu (Phillipson, 1992), tak kvůli jisté ztrátě relevance pojmu ideálního rodilého mluvčího ve světě, kde se komunity cílových zemí stávají jazykově i kulturně stále různorodější. S otázkou rodilého mluvčího je spojena i otázka vlastnictví angličtiny (ownership of English). Phillipson (1992) pojednává o tzv. jazykovém imperialismu (language imperialism), který kritizuje rozšíření a prosazování dominance angličtiny, protože v něm spatřuje nástroj kolonialismu. Phillipson také tvrdí, že v procesu globálního rozšíření a používání se angličtina stala jazykem mezinárodním, a tak i „vlastnictvím“ celého světa. Pro nás je koncept dominance anglického jazyka a kultury zajímavý ve vztahu k výuce angličtiny jako cizího jazyka, jelikož vycházíme $\mathrm{z}$ předpokladu, že postoje nadřazenosti nebo podřízenosti rodilých, respektive nerodilých mluvčích negativně ovlivňují učení a že vnímaná politická, ekonomická a kulturní rovnost mezi 
jazykovými skupinami naopak vede k efektivnějšímu osvojování cizího jazyka (Schumann, 1981, s. 15).

Jeden z nejvýznamnějších autorů publikujících na téma kultury ve výuce cizích jazyků, Michael Byram, nedávno napsal, že zastřešujícím cílem jazykového vzdělávání by měl být rozvoj interkulturního občanství (intercultural citizenship), tj. „kompetence zapojit se do politické aktivity s lidmi z jiných lingvistických a kulturních oblastí jak v rámci jedné země, tak v prostoru přesahujícím hranice států" (Byram, 2011, s. 19, překlad autorky). Podobně Kostková (2012) uvádí, že vyučování/učení se cizím jazykům bývá označováno za jeden z klíčových prostředků vedoucích k rozvoji interkulturní komunikační kompetence, a tím k efektivní komunikaci v multikulturní Evropě. Tento požadavek vidíme zrcadlit se i v českých vzdělávacích dokumentech a pedagogické literatuře (Průcha, 2001, 2004). Rámcový vzdělávací program pro gymnázia (2007) se v kapitole cizí jazyk sice, co se týče učiva, tradičně zaměřuje hlavně na reálie zemí studovaného jazyka, otázky integrace v multikulturním prostředí však pojednává v oblastech multikulturní výchovy a výchovy k myšlení v evropských a globálních souvislostech, tedy průřezových tématech, $\mathrm{k}$ nimž by měl předmět cizí jazyk přispívat. Multikulturní výchova se zaměřuje na „poznání a pochopení kulturních diferencí mezi lidmi nejrůznějšího původu, mezilidské vztahy, interkulturní komunikaci a přizpůsobení životu v multikulturní společnosti“ (RVP, 2007, s. 73). V tomto průřezovém tématu by se však výuka neměla omezit jen na získávání informací, nýbrž snažit se také „stimulovat, ovlivňovat či korigovat postoje, hodnotový systém a jednání žáků, posilovat jejich schopnosti začlenit se do multikulturních aktivit a být úspěšní v mezinárodní spolupráci“ (RVP, 2007, s. 73). Ve výchově k myšlení v evropských a globálních souvislostech je zdůrazněn problém nerovnosti, at' už mezi zeměmi, tak mezi jednotlivci nebo pohlavími, např. v prř́stupu ke vzdělávání (RVP, 2007, s. 72).

Vyvstává tedy otázka, do jaké míry se daří nastolovat a didakticky „otevírat" multikulturní témata $v$ učebnicích anglického jazyka, které jsou popisovány jako velká autorita ve vytváření kulturních a lingvistických identit (Shardakova \& Pavlenko, 2004, s. 28). Výrok o učebnici jako uznávaném nositeli legitimních poznatků a hodnot platí zvláště v prostředí, kde studenti nejsou běžně v bezprostředním kontaktu s kulturou zemí studovaného jazyka, jako je tomu $\mathrm{v}$ př́padě studentů anglického jazyka u nás. $\mathrm{V}$ tomto textu tedy analyzujeme obsahové vlastnosti učebnice anglického jazyka určené českým 
studentům. Konkrétně jsme pro analýzu zvolili koncept identity, protože postavy zobrazované $\mathrm{v}$ učebnicích jsou pro studenty reprezentanty kultury cílové země/zemí, ke kterým se studenti vztahují a podle nichž si mohou vědomě či nevědomě vytvářet představy o celém společenství.

Schopnost nalezení a ustálení vlastní identity v roli prostředníka mezi kulturami je také podle Jensena, Jaegera a Lorentsena (1995, cit. podle Block, 2007, s. 118) součástí interkulturní kompetence. Společný evropský referenční rámec pro jazyky specifikuje interkulturální způsobilost jako znalosti, uvědomění a pochopení podobností a odlišností mezi světem studentů a světem cílového společenství včetně jejich regionální a sociální různorodosti (SERR, 2002, s. 105). Zajímá nás tedy, jaké možnosti identit nabízí učebnice a zda se v ní objevují úkoly, které u studentů rozvíjí interkulturní kompetenci. Konkrétně se zaměříme na úkoly vedoucí k ocenění vlastní i cizí kultury, jejich relativity a úkoly vedoucí k nalezení vlastního interkulturního stylu a identity (srov. Crozet \& Liddicoat, 1999). Koncept identity a výzkumy na něm založené přibližujeme $v$ následujícím oddíle.

\section{Identita ve výuce cizích jazyků}

Identita je obecně vnímána jako to, kdo jsme a čím jsme. Definice identity založená na poststrukturalistických teoriích zdůrazňuje důležitou vlastnost identity, a to její proměnlivost, křehkost a možné narušení napřr. vlivy globalizace (srov. Hyland, 2012). Obecně panuje shoda na tom, že existují různé druhy identit a že identita znamená identifikaci se širší kategorií, např. žen, rodičů, sportovců apod. Jiným aspektem identity je to, že jsme zvyklí vnímat svou identitu jako něco, co existuje nezávisle na začlenění se do určité sociální skupiny a rolích nebo vztazích, které v těchto skupinách navazujeme. Sociálně konstruktivistické pojetí identity naopak nenahlíží na identitu jako na kategorii vztahující se pouze k jednotlivé osobě, ale jako na kategorii, která je utvářena mezi lidmi v sociálních interakcích (Berger \& Luckmann, 1999). Identita tedy není stavem, ale spíše procesem, tedy něčím, co se utváří a mění v čase skrze interakce s ostatními.

V našem výzkumu vycházíme převážně z práce Nortonové $(2000,2001)$, která identitu chápe jako vztah mezi jednotlivci a širším sociálním světem, tak jak je spoluutvářen institucemi jako je rodina, škola, práce atd. Hlavními složkami identity jsou rasa, etnicita, gender a společenská třída. Nortonová zasazuje otázky spojené s učením cizích jazyků do sociálního kontextu, 
např. si všímá toho, jak některé identity mluvčích ve vztahu ke komunitě cílového jazyka omezují nebo naopak facilitují prŕležitosti k procvičení mluvení, poslechu, psaní a čtení. Nortonová vychází z Westa (1992), když argumentuje, že identita odkazuje na touhu, tedy touhu po uznání, sounáležitosti a bezpečí. Tyto touhy však autorka vidí jako závislé na přístupu k materiálním zdrojům společnosti. Lidé, kteří se těší tomuto přístupu, mají větší moc, což zase zpětně ovlivňuje to, jak sami chápou svůj vztah ke světu a své možnosti jej formovat. Nortonová pracuje se vztahem mezi identitou a tzv. symbolickou mocí, jak ji popisuje Bourdieu (1977). Jedním z jejích tvrzení je to, že hodnotu připisovanou promluvě nelze posoudit bez zohlednění toho, kdo promluvu pronáší a také bez znalosti širších sociálních vztahů této osoby. Nortonová $(2000$, s. 8$)$ usiluje o zviditelnění faktu, že pouze některým mluvčím se dostává práva mluvit, aniž bychom tato práva zpochybňovali, a mění tak náš dosavadní pohled na teorie osvojování jazyka, když navrhuje začlenit do definice komunikační kompetence právo mluvit (angl. the right to speak). Psychologický konstrukt motivace v učení se cizím jazykům doplňuje pojmem investment, který zde překládáme jako nasazení, tedy konstruktem, který propojuje snahu a odhodlání ovládnout cizí jazyk s realitou jazykové komunity nebo školní třídy, kde se výuka odehrává. Někteří mluvčí mohou zažívat diskriminaci nebo vnitřní konflikty s vlastní identitou a jejich př́ležitosti k učení a v souvislosti s tím i jejich nasazení je omezováno.

V tomto kontextu je vhodné zmínit další konstrukty, které se ve výzkumu identity objevují, a to tzv. představa společenství (angl. imagined community, Anderson, 2008) a možných já (angl. possible selves, Markus \& Nurius, 1986). Oba pojmy lze chápat v kontextu výše zmíněného konstruktu nasazení v učení se cizímu jazyku, protože představy o komunitě cílového jazyka a vlastních možnostech, které mluvčím může nabídnout, mohou v učení sehrát významnou roli.

Některé výzkumy obrací pozornost také k sociokulturním identitám učitelů cizích jazyků a jejich reprezentacím ve výuce (např. Clarke, 2008; Duff \& Uchida, 1997). Jenkinsová (2007) ve svém výzkumu o postojích a identitách nerodilých učitelů angličtiny zjistila, že někteří z nich trpí tzv. ,jazykovou schizofrenií" vyvěrající z konfliktu mezi jejich identitou v rodném jazyce, kde učitelé cítí sepětí se svou národní identitou, a na druhé straně identitou učitele, ve které usilují o co nejbližší napodobení přízvuku rodilých mluvčích, nebot' si ho spojují s úspěchem ve své profesi. 


\section{Výzkumy identity v učebnicích cizího jazyka}

Identita $\mathrm{v}$ učebnicích cizích jazyků se dostala do popředí zájmu poměrně nedávno, první studie se objevují od 90. let (např. Canagarajah, 1993; Gray, 2002; Azimova \& Johnston, 2012; Melliti, 2013). Pozornost věnovaná identitě jako zastřešujícímu pojmu pro různé sociální role, vztahy a zastávané hodnoty v jejich proměnlivosti se zdá být jakýmsi logickým přesahem či rozšířením dř́vějšího častého zájmu o gender jako základní výzkumnou kategorii (v učebnicích cizích jazyků např. Hartman \& Judd, 1978; Porreca, 1984; Stephens, 1990; Sunderland, 1992; Radimský, 2001).

Základním východiskem většiny výzkumů identity v učebnicích je pohled na učebnice jako na nástroje pro přenos norem a hodnot (Apple, 1992). Společná je těmto výzkumům také potřeba zviditelňování tzv. dominantních diskurzů, které jsou v učebnicích skryty. Např. Shardaková a Pavlenková (2004) ve své studii učebnic ruštiny určených pro anglicky mluvící uživatele zjistily, že identitami, které učebnice zobrazuje, jsou převážně bílí, středostavovští muži, kteří žijí ve velice pohodlném a jednoduchém světě. Jejich jazykové znalosti jsou tak rozsáhlé a zobrazené postavy jednají tak sebejistě, že to může být pro začátečníky, jimž je učebnice určena, až zastrašující. Podobně koncipovaná učebnice také neposkytuje př́ležitosti naučit se vyjednávat a řešit nedorozumění, uzavírají autorky. Shardaková a Pavlenková kombinují metody analýzy, když pro přehlednější a komplexnější prezentaci svých zjištění kromě kritické analýzy diskurzu používají i obsahovou analýzu.

Příkladem výzkumu používajícího výhradně obsahovou analýzu je studie Matsudové (2002), která zvolila jako základní kategorii národnost, aby poukázala na identity postav představujících v japonské učebnici mluvčí angličtiny. Autorka výzkumu zjišt'uje, že většina zobrazených postav je z Japonska nebo zemí tzv. vnitřního okruhu, v tomto prrípadě konkrétně z USA, Kanady, Austrálie a Skotska. Výzkumu identity ve výuce cizích jazyků se v současnosti v západních zemích věnuje velká pozornost, v českém prostředí se nám však konkrétně $\mathrm{v}$ oblasti výzkumu učebnic cizích jazyků zatím nepodařilo nalézt studie založené na tomto konstruktu. 


\section{Analýza učebnice}

\subsection{Cíle a výzkumné otázky}

Hlavním cílem studie je popsat národní, etnické, genderové a sociální aspekty identit postav $\mathrm{v}$ učebnici anglického jazyka určené českým studentům středních a jazykových škol Time to talk (2001-2004). Dále si klademe za cíl popsat způsoby omezování možností interpretace kulturních sdělení v textech a úlohách. V neposlední řadě se pokusíme potenciál učebnice pro mezikulturní reflexi vztáhnout k cílům multikulturní výchovy, tak jak je deklaruje Rámcový vzdělávací program (2007). Konkrétně si klademe tyto výzkumné otázky:

1. Jaké jsou identity postav zobrazovaných v učebnici po stránce národnostní, etnické, genderové a sociální?

2. Jakou představu společenství mluvčích anglického jazyka učebnice vytváŕí?

3. Jak probíhá interakce mezi postavami z anglicky mluvících zemí a Česka?

4. Jak učebnice otevírá/uzavírá $\mathrm{v}$ doplňujících úlohách možnosti práce s kulturními obsahy textů?

\subsection{Zkoumaný soubor a metodologie}

Učebnice Time to talk (dále TtT) vychází od roku 2001, poslední čtvrtý díl vyšel roku 2004. Učebnice splňovala naše kritéria pro volbu tím, že podle výzkumu Koláčkové (2011) patří v současnosti mezi čtyři nejčastěji používané učebnice AJ na středních školách v Brně a okolí, mezi volenými učebnicemi navíc jako jediná reprezentuje českou produkci. $V$ neposlední řadě byl pro nás důležitý i fakt, že učebnice byla schválena MŠMT ČR.

Ve všech dílech učebnice (1-4) analyzujeme texty (včetně poslechových) a doprovodné ilustrace, které zachycují postavy v kontextu. Texty zde chápeme jako reprezentace, jinými slovy analyzujeme konceptuální strukturu, kterou text evokuje u čtenářů, světy, které si mohou na základě textů představit, vztáhnout se k nim a považovat za skutečné (Krippendorf, 2013, s. 66).

V první fázi výzkumu vybíráme relevantní jednotky dle zvolených kategorií, tedy ty, které vypovídají o národnosti, etnicitě, sociálním statusu nebo genderu postav, a jednotky, ve kterých je zachycena interkulturní komunikace. Jednotkami jsou pro nás jak věty, tak celé texty (Švec, 1998) 
a ilustrace. Vzhledem k prolínání jednotlivých kategorií v identitách postav (např. gender a sociální tř́da, národnost a etnikum) mohou být některé jednotky vybrány do vícera kategorií. Během kódování se také ukázalo jako vhodné rozlišit postavy fiktivní a historické a věnovat se jim odděleně. V kategorii národnostních identit postav zaznamenáváme jak explicitní národnostní identifikaci v textu, tak implicitní národnost danou kontextem. Napřr. pokud postava popisuje britský vzdělávací systém, označujeme ji jako britskou. Zobrazené národnostní identity postav kvantifikujeme, nebot’ kvalitativní analýza ukázala, že patří do 4 základních skupin, tedy britská, americká, česká, jiná. V ostatních kategoriích (identita etnická, genderová a sociální) kvantifikaci neprovádíme, nebot' její výsledky vidíme jako ne př́liš relevantní a tyto jednotky analyzujeme pomocí jiných metod $\mathrm{v}$ dalších fázích analýzy. Sociální identitu charakterizujeme v souladu s Šafrem (2008, s. 68) dle těchto vybraných kritérií: příjem, sociální postavení, vzdělání, rodinné zázemí, životní styl, povolání. Genderovou identitu konceptualizujeme prostřednictvím genderových rolí, zaměřujeme se tedy na způsob, jak učebnice popisuje chování očekávané od členů dané společnosti v souvislosti s jejich pohlavní př́islušností (Renzetti \& Curran, 2003, s. 24).

Ve druhé fázi vybrané jednotky zkoumáme pomocí kritické analýzy diskurzu. Jedním ze základních pilírư této metody jsou myšlenky Foucaulta (1972), který definoval diskurz jako rozpoznatelný systém vystavěný opakujícími se sděleními a formulacemi napříč texty. Analýza diskurzu je proto pro nás vhodným nástrojem, který nám pomáhá demonstrovat, jak tento systém utváří subjekty a světy, o kterých pojednává, a také pravidla pro to, co lze a co nelze v rámci určitého diskurzu říct (Jörgensen \& Philips, 2002, s. 13). V kritické analýze diskurzu neexistuje žádný fixní soubor analytických konceptů, proto bývá metodologicky značně eklektická (Wodak \& Meyer, 2009). My v této studii analyzujeme vybrané jednotky pomocí několika nástrojů kritické analýzy diskurzu. Konkrétně se zaměřujeme na modalitu, která, jak uvádí Hodge a Kress (1993, s. 122), znamená vlastně moc, protože stanovuje stupeň autority výroku. Modalita je běžně vyjádřena způsobovými slovesy (např. muset, nesmět) nebo i slovesy jako „tvrdím“, „pochybuji“, nebo příslovci jako např. „rozhodně“. Pracujeme také s konceptem předpokladu (presupposition), což jsou implicitní sdělení o světě, která autoři používají pro prezentaci myšlenek, které by podle nich měly být akceptovány bez zpochybňování (Huckin, 1997), nebo konotacemi, tedy slovními asociacemi. 
Významnou a neopomenutelnou součástí učebnice cizích jazyků jsou úlohy, ve kterých mohou autoři kulturní obsahy nabídnout ke zpracování, tedy potvrzení nebo zpochybnění, vztažení k vlastní identitě. Ve třetí fázi šetření jsme proto obsahovou analýzu a kritickou analýzu diskurzu vybraných textových jednotek doplnili analýzou úloh a klíče pro učitele. Tato metoda vychází z konceptu otevřeného a uzavřeného textu (Eco, 1979, 2010) a s její pomocí ukazujeme, jak je determinována interpretace. Text podle Eca odkazuje na existující znalosti a kompetence a může je bud' „otevřít“ - rozvinout, přehodnotit, extrapolovat nebo přeházet, nebo text současné znalosti „uzavře" - stanovením nebo posílením dřívějších znalostí, konvencí a názorů. V uzavřeném textu nám autor přesně sdělí, který výklad jeho textu je jediný správný, napřr prostřednictvím vypravěče (Luke, 1989, s. 69). Otevřený text naopak generuje nepředvídané interpretace, rozehrává různé významy a buduje odpovídající možné světy. Možné světy jsou pojmem pocházejícím původně z filozofie, Eco ho však rozpracoval pro teorii fikce. Tyto možné světy, které úzce souvisí s modalitou popsanou výše, jsou světy, které si představujeme, ve které věříme, které si přejeme (Eco, 1979, s. 219). V této analýze nám možné světy mohou pomoci definovat postavy zobrazené v učebnici prostřednictvím jejich představ a snů.

Je na místě přiznat, že tato analýza je motivovaná a ovlivněná světonázorem autorky, jsme však přesvědčeni, že analýza diskurzu musí být kritická, nejen deskriptivní, a to nikoli proto, že autoři analýz jsou nebo chtějí být politicky angažovaní, ale protože „politický“ je samotný jazyk, tím, jak ovlivňuje distribuci sociálních prostředků (Gee, 2011, s. 9). Pokud učebnice vidíme jako oficiální prostředek pro šíření znalostí, je podle nás na místě kriticky prozkoumat ideologické obsahy, které v nich bereme za samozřejmé. V této studii se nám jedná zejména o zviditelnění sociálních nerovností.

\subsection{Výsledky}

\section{Národnostní identity}

Jednoznačně nejčastější národností, kterou lze identifikovat mezi fiktivními postavami v učebnici, jsou Britové (konkrétně 48 postav), pouze 4 postavy jsou ze Spojených států amerických a 6 postav je z České republiky. Britové dominují i mezi prezentovanými historickými postavami: 5 z nich lze zařadit mezi britské (Ch. Brontë, W. Shakespeare, O. Wilde, L. Carroll, Ch. Dickens), dvě postavy jsou americké národnosti (F. S. Fitzgerald, M. L. King), jednu postavu lze přiřadit k českému kulturnímu prostoru (císař Rudolf II.) a jednu postavu klasifikujeme jako jinou (Matka Tereza). 


\section{Etnické identity}

Všechny fiktivní postavy, které jsou zobrazeny v ilustracích, mají bílou barvu pleti, pouze na jednom obrázku, doplněném popiskem „traveller“ (cestovatel), jsou v pozadí domorodci tmavé pleti s bederními rouškami a výraznými šperky (TtT 1, s. 45) a velice podobné osoby jsou zobrazeny i na obrázku, který ilustruje práci zahraničního korespondenta (TtT 4, s. 98). Tento způsob zobrazení považujeme za etnocentrický, protože jinou kulturu poměřuje podle naší, která je navíc $\mathrm{v}$ tomto případě v nadřazené roli. Jediná plnohodnotně zobrazená postava tmavé pleti je Martin Luther King, jehož životu a boji proti rasové diskriminaci je věnován celý článek (TtT 4, s. 111).

\section{Sociální identity}

Postavy mladých lidí, nejčastěji definované jako studenti, nebo jimi popisovaní blízcí, sní o tom, jak jednou budou pracovat pro charitu a pomáhat bezdomovcům nebo dětem (TtT 2, s. 8), pracovat jako veterináři (TtT 1, s. 81), studovat francouzštinu (TtT 1, s. 46) nebo studovat na univerzitě (TtT 1, s. 56). Zobrazovaný svět je, co se týče sociokulturního statusu, celkově na značně vysoké úrovni: rodiče postav nebo jiných dospělých mají ve většině př́ipadů prestižní profese, jsou např. lékaři, veterináři, spisovateli, módními návrháři, architekty, učiteli, umělci. Málo placená nebo manuální práce je uvedena pouze několikrát, a to hlavně u studentů, kteří si přivydělávají u studia, např. dívky jako číšnice nebo au-pair. Práce je popisována jako důležitá složka života - patří do všech obsáhlejších medailonků a charakteristik osob, pouze $\mathrm{v}$ jedné $\mathrm{z}$ učebnic se objevila zmínka o nezaměstnaném, který už je však na cestě na pohovor na novou práci (TtT 2, s. 118). Typická je také rodinná soudržnost - v učebnici prakticky nenalézáme zmínku o neúplných rodinách. Vyššímu společenskému statusu odpovídá i úroveň bydlení postav - např. Dawsonovi bydlí u velkého parku v tř́ípokojovém domě se zahradou a garáží (TtT 1, s. 22), Parksovi se stěhují do domu s velkou zahradou (TtT 1, s. 69), ilustrace dívky z Pařriže ukazuje její pokoj s výhledem na Eiffelovu věž (TtT 1, s. 109). Specifickým př́ípadem je rodina mravencủ, která bydlí v okázalém domě s pěti pokoji, pracovnou a kouzelným výhledem do lesa (TtT 1 , s. 58) - v tomto pohádkovém př́běhu je poněkud problematické stanovovat sociální status obyvatel, dá se však soudit, že v této učebnici dokonce i životní úroveň v mraveništi vysoko přesahuje standard bydlení průměrné české rodiny. Na konci lekce dostávají studenti úkol popsat byt nebo dům svých snů (TtT 1, s. 69). 


\section{Genderové identity}

Jedním ze zdrojů konfliktů dospělých postav v učebnici je gender a rozdělení rolí mužů a žen, např. Carla (TtT 2, s. 119) je zpěvačkou, která miluje svou práci, ale vadí jí, že hodně cestuje a nemá proto čas na rodinu. Žádná mužská postava podobný problém neřeší. Zajímavý je také předpoklad cvičení nadepsaného Mamka stávkuje (TtT 1, s. 102), kde matka rozdává úkoly celé rodině a je tedy zřejmé, že běžný úděl „nestávkující" matky je tyto práce dělat sama. V zadání cvičení je uvedeno, že při formulaci požadavků má být použito způsobových sloves can a could (můžeš, mohl bys), stávkující matka tak formuluje požadavky velice zdvořile, což se zdá být v rozporu s dramatickým titulkem cvičení. Stojí také za zmínku, že matka zadává úkoly i otci (konkrétně „umýt auto“ a úsměvné „sklidit si své čisté košile“), kromě dětí se tak i otec a jeho nedostatečné zapojení do domácích prací stává jedním z podnětů $\mathrm{k}$ matčině vzpouře a spíše než o vymezování práv a povinností mezi rodiči a dětmi jde o tzv. „boj mezi pohlavími“, dojem je umocněn zvolením slova s negativními konotacemi „stávkuje“. Ženy častěji než muži zastávají hůře placená zaměstnání a spíše se realizují jako výtečné kuchařky, dekoratérky svých domácností a hospodyně (TtT 1, s. 30, 58, 68, 71, 130). Mladé zamilované dívky jsou roztěkané v práci (TtT $1, \mathrm{~s} .22)$ a vyžadují od svých chlapců různé pozornosti, např. od Kevina květiny, on však na to není „dost romantický" (TtT 2, s. 100). Komunikace mezi příslušníky obou pohlaví je komplikovaná jejich milostnými touhami, např v jednom ze cvičení na osvojení způsobových sloves (can't a have to, tj. nemoci a muset) stojí v zadání, aby studenti pomohli Claire vymyslet výmluvy na celý týden, aby nemusela na schůzku se svým ctitelem Davidem, který ji vytrvale přemlouvá (TtT 1, s. 90). Uzavřený typ cvičení nedává možnost postupovat v rozhovoru jinak než dle předlohy a vytváŕí či stvrzuje u čtenáře předpoklad, že osoby opačného pohlaví běžně hrají sofistikované - zde i neupřímné konverzační hry. V textu třetího dílu učebnice je genderová tematika prezentována odlišně, když v novinovém článku píše učitelka o nedostatku respektu rodičůn, zvláště otců, k práci učitelů/učitelek: „Often it's fathers who think we're just women who like children and have nothing else to do and aren't clever enough to do 'real' jobs." (Často jsou to otcové, kteří si myslí, že jsme jen ženy, co mají rády děti a nemají nic jiného na práci a nejsou dost chytré na to, aby dělaly „pořádnou“ práci.) (TtT 3, s. 86). V následujícím úkolu se studenti mají vyjadřovat k častým výrokům činěným na adresu učitelů, např. o tom, že učitelé mají štěstí, protože mají dlouhé prázdniny, nebo si představit, že jsou sami učiteli 
na státní škole a připravují si řeč o problémech, se kterými se potýkají ve své práci. Nejenže se zde ženám ve feminizovaném školství dostává hlasu, stereotypní výroky o jejich práci jsou navíc předloženy k diskusi a studenti se mají vžít do jejich role, což celý text otevírá a umožňuje nahlédnout na problém z různých perspektiv.

\section{Představa společenství}

Z analýzy národnostních, etnických a sociálních postav identit vyplývá, že učebnice jako cílové společenství chápe zejména britské kulturní prostředí, které však vykresluje jako etnicky a sociálně poměrně homogenní. Život komunity zobrazené hlavně v prvních dvou dílech učebnice je velmi př́ijemný, s oblibou a často se zde pořádají nejrůznější večírky (TtT 1, s. 70, 72, 80), rodiny žijí pohromadě a kromě drobných sourozeneckých sporů týkajících se např volby domácích mazlíčků (TtT 2 , s. 134) ve velké pohodě a komfortu. Pokud se zaměříme na modalitu v textech, tedy např. na použití způsobových sloves jako muset nebo nesmět, zjištujeme, že v zobrazeném světě patř́ mezi hlavní povinnosti studovat, chodit včas na schůzky a nejíst moc sladkostí, abychom neztloustli (TtT 2, s. 112).

\section{Interkulturní prvky}

Mezi postavami z Británie a Česka dochází často k setkání a konfrontaci, takto např. popisuje svůj britský student David svou zkušenost s Čechy v dopise kamarádce: „I must say they looked mostly quite serious, but people were very polite and helpful to us." (Musím říct, že většinou vypadali dost vážně, ale byli velmi zdvořilí a ochotní pomoci.) (TtT 1, s. 108). Když britský dokumentarista natáčí pořad o České republice (TtT 4, s. 34-25), popisuje „smíšené pocity“ Čechů o vlastní zemi a jejích obyvatelích, jako Brit však vnímá hlavně nádhernou krajinu, půvabné hlavní město a moravskou pohostinnost. Celý článek vyznívá jako reklamní sdělení pro Brity, aby v Česku navštívili více než jen Prahu. Ve stejné lekci v dopise kamarádovi popisují Britové, jak si v Česku užívají: „We're having the time of our lives in this lovely country“ (Máme se v téhle nádherné zemi prostě báječně. TtT 4, s. 44), a zdůrazňují, že ani šest týdnů, které na poznávání země mají, není dostačující doba. Úkolem pro studenty je pak naplánovat měsíční cestu po Česku pro kamaráda nebo kamarádku z ciziny (TtT 4, s. 45). 
Autoři se pokouší nastolovat otázky národních stereotypů, např. když David v dopise popisuje "some strange ideas“ - zvláštní představy Čechů o Anglii, např. takovou, že v Anglii všichni jí šunku s vejci a milují Sherlocka Holmese (TtT 1, s. 108). Ve cvičení ve stejné lekci knihy (s. 117) jsou studenti vyzváni, aby si představili své setkání s Davidem v jazzovém klubu a položili mu otázky o Anglii, čímž se otevírá možnost formulovat a dále diskutovat představy samotných studentů. V některých dalších textech je také zřetelná snaha o podporu mezikulturního poznávání a porozumění - např. učitelka vyjadřuje pochopení k nedorozumění způsobenému kulturní odlišností: „She said she'd probably make a similar mistake if they sent her to school in England." (Ř́kala, že by asi udělala podobnou chybu, kdyby ji poslali do školy v Anglii. TtT 3, s. 111). Jinde nacházíme otevřenou kritiku a stereotypní vnímání jedné kultury druhou, např. toto je prezentovaný britský názor na Spojené státy:

It makes me really cross, the way everything is influenced by the USA. From international politics to what we watch on television. I mean, let's be honest, most of us in Britain probably feel the same way, don't we? [Opravdu mě rozčiluje, jak je všechno ovlivňováno Spojenými státy. Od mezinárodní politiky po to, na co se díváme v televizi. No upř́mně, většina nás v Británii si to myslí, nebo ne?] (TtT 4, přepis poslechového cvičení s. 84).

Americký mluvčí ve stejném cvičení podává obdobně stereotypní pohled z druhé strany:

Everyone's running around working real hard and being very busy, but I just don't feel the energy here that I feel back home. [...] Also, Americans, I think, have a very strong sense of the future, in Britain I feel pulled towards the past. (Všichni tady pobíhají, tvrdě pracují, nemají na nic čas, ale já opravdu necítím tu energii, co doma [...] Taky se mi zdá, že Američani se víc dívají do budoucna a v Británii jako by mě to táhlo zpátky do minulosti). (TtT 4, přepis poslechového cvičení s. 84).

Tyto poměrně jednostranné názory pak nejsou dál nijak zpracovávány, ukazují však, že stereotypy či předsudky, tedy až nepřátelské postoje vůči jiným skupinám (Průcha, 2004, s. 68) jsou univerzálním prvkem ve většině kultur. Otevřenější je text o cizincích, kteří žijí v Česku a vyprávějí o svých pozitivních i negativních zkušenostech (TtT 4, přepis poslechového cvičení, s. 45). Studenti s materiálem dále pracují tak, že rozebírají uvedená kontroverzní tvrzení o Češích, mají za úkol napsat krátký životopis někoho ze slavných Čechů žijících v zahraničí nebo mluvit o tom, které významné české osobnosti by pozvali na večeři na počest své vlasti (TtT 4, s. 47). 
Postavy z anglofonního světa studují nebo už mluví nejrůznějšími jazyky, od francouzštiny a italštiny po němčinu, pokud však korespondují nebo jinak komunikují s českými mluvčími, neumí kromě „čau“ (TtT 4, s. 31) žádná další česká slova (sic). Britský turista oceňuje výbornou angličtinu mladých lidí, reflektuje však také „legrační chyby“, kterých si všímal na anglických mutacích jídelních lístků v českých restauracích (TtT 1, s. 108). Také Britka Rachel je v roli arbitra jazykových znalostí své české kamarádky Marcely, které s potěšením uděluje kompliment o tom, jak málo gramatických chyb dělá, ačkoli to většinou „není případ zahraničních studentů, zvláště pokud jde o předpř́ítomný čas" (TtT 4, s. 136). Dává jí zároveň několik tipů na to, jak si efektivně osvojovat slovíčka.

Pozornost je věnována rozdílům mezi americkou a britskou angličtinou, rozdílům mezi americkým a britským vzdělávacím systémem a rozdílům mezi anglickou a českou kulturou. Častým postupem je prezentování jevu anglické kultury a zadání úkolu pro studenty, aby jej porovnali s českým ekvivalentem, např. nejzajímavější turistické destinace v Británii a Česku (TtT 2, s. 133). Jiný typ cvičení je ten, kde se kultury potkávají, např. když v zadání úkolu stojí, aby studenti diskutovali o tom, čím by naplnili vánoční punčochu, pokud by chtěli př́tele v Anglii obdarovat typickými českými dárky (TtT 2, s. 31), nebo když mají změnit slova tradiční anglické koledy tak, aby platil pro české Vánoce (TtT 2, s. 35).

\section{Shrnutí a diskuze}

Co se týče identit v učebnici, patří zobrazené postavy mezi střední až vyšší třridu a pochází hlavně z Velké Británie. Autoři téměř nedávají hlas marginalizovaným sociálním, etnickým a genderovým skupinám a texty tak neodráží pestrou realitu společenství mluvčích angličtiny $\mathrm{v}$ globalizovaném světě. Je ale paradoxně zřetelné, že učebnice respektuje současný diskurz kulturní inkorporace, o kterém píše Apple (1992, s. 8), tedy začlenění různých kulturních skupin a jejich zájmů do učebnice. Můžeme to $\mathrm{v}$ př́padě etnicity ilustrovat např. na článku o M. L. Kingovi, ve kterém se dovídáme o boji za lidská práva $\mathrm{v}$ Americe, ovšem nikde jinde $\mathrm{v}$ knize nenajdeme postavu jiné barvy pleti než bílé, která by nebyla zobrazena stereotypně. Podobně se sice v jednom případě do hloubky zamýšlíme nad problémy žen ve školství, celkově jsou však ženy zobrazovány v méně prestižních povoláních. Učebnice tak pouze částečně přispívá ke splnění cílů multikulturní výchovy a výchovy k myšlení 
v evropských a globálních souvislostech, když sice podporuje zapojování do multikulturních aktivit, avšak nezabývá se otázkou sociálních nerovností, naopak reprodukuje stereotyp o sociálně monolitické společnosti zneviditelněním chudoby a sociálních nerovností. Podobná zjištění přináší napřr. studie Tomlinsona a Masuhary (2013), kteří konstatují, že současné britské učebnice angličtiny jako cizího jazyka určené pro mezinárodní trh předpokládají ambiciózní, středostavovské, vzdělané uživatele, nebo výzkum Johna Graye (2010), který v globálních učebnicích angličtiny popisuje spojení používání angličtiny s úspěchem, individualismem a bohatstvím.

Značná pozornost je věnována české kultuře, čímž se podporuje vědomí vlastní identity českých studentů, jeden $\mathrm{z}$ cílů je seznámit studenty s reáliemi zemí jazyka, ale také zvýšit povědomí o vlastním kulturním dědictví, které je zde viděno očima nadšených zahraničních návštěvníků. Pokud máme ale odpovědět na otázku v názvu tohoto článku, musíme konstatovat, že angličtina $v$ této učebnici patřri rodilým mluvčím, konkrétně Britům, kteří jezdí do Česka jako turisti, obdarovávají české přátele knihami o Británii (TtT 2, s. 22) a komentují úroveň jazykových znalostí místních obyvatel. Čeští studenti angličtiny se připravují na roli průvodců v domácím prostředí nebo turistů v anglicky mluvících zemích.

Učebnice otevírá v zadání úkolů prostor pro kritické nahlédnutí jak na cílovou, tak na vlastní kulturu a umožňuje tak studentům zpochybnit či přehodnotit některé své názory a postoje. Popsali jsme otevřené typy úkolů, ve kterých mají studenti volně vyjádřit vlastní názor, objevili jsme však i značně problematická uzavřená cvičení, která studentům neumožňují splnit správně úkol, aniž by reprodukovali ideologicky zabarvený názor autorů. Tento typ ideologického přenosu zůstává ve výuce často nepovšimnut, nebot' pozornost se většinou zaměří na jazykovou správnost, nikoli na obsah sdělení a může tak u studentů přispět k vytvoření stereotypních názorů. Jsme si samozřejmě vědomi toho, že učebnice jsou pouze jedním ze zdrojů, které působí na vytváření hodnotových orientací (Průcha, 1998, s. 91), domníváme se však, že př́lišné zjednodušování, nedostatečné zastoupení nebo stereotypní zobrazování těchto imaginárních světů a komunit může vést nejen ke snížení motivace $\mathrm{k}$ učení, ale také $\mathrm{k}$ mezikulturním nedorozuměním, frustracím a konfliktům. Věříme také, že pokud budou žáci považovat anglický jazyk za „svůj“ a budou se považovat za jeho legitimní mluvčí, bude to mít pozitivní vliv na jejich učení. 
Jaké závěry lze z této práce vyvodit pro pedagogickou praxi? Předně bychom chtěli zdůraznit, že učitelé cizích jazyků by si měli být vědomi toho, jaká sdělení $\mathrm{z}$ jejich výuky mohou vyplývat, proto by bylo vhodné vést je už $\mathrm{v}$ učitelském vzdělávání ke kritické reflexi jak obsahů učebnic, tak vlastních postojů k aktuálním tématům multikulturní výchovy a výchovy k myšlení v evropských a globálních souvislostech, ke kterým má cizojazyčná výuka přispívat. Důležité je věnovat se také způsobům používání učebnice, na kterou se někdy jako nerodilí mluvčí cizího jazyka až příliš spoléháme, a vést $\mathrm{s}$ žáky o předkládaných tématech otevřený dialog, př́ípadně se nebát vyhledávat, zpracovávat a používat materiál pokrývající témata, která jsou v učebnicích opomíjena. Používání autentických materiálů, otevřených typů úloh a vytváření výukových situací, ve kterých mohou žáci rozehrát různé své identity, může vést $\mathrm{k}$ jejich většímu emočnímu zapojení a tím i zvýšení motivace a učení.

\section{Literatura}

Anderson, B. (2008). Představy společenství: úvahy o původu a šírení nacionalismu. Praha: Karolinum.

Apple, M. (1992). The text and cultural politics. Educational Researcher, 21(7), 4-19.

Azimova, N., \& Johnston, B. (2012). Invisibility and ownership of language: Problems of representation in Russian language textbooks. The Modern Language Journal, 96(3), 337349.

Berger, P., \& Luckman, T. (1999). Sociální konstrukce reality: pojednání o sociologii vědění. Brno: Centrum pro studium demokracie a kultury.

Block, D. (2007). Second language identities. London: Continuum.

Bourdieu, P. (1977). The economics of linguistic exchanges. Social Science Information, 16(6), 645-668.

Byram, M. (1990). Intercultural education and foreign language teaching. World Studies Journal, $1(7), 4-7$.

Byram, M. (2011). Intercultural citizenship from an international perspective. Journal of the NUS Teaching Academy, 1(1), 10-20.

Canagarajah, S. (1993). American textbooks and Tamil students: Discerning ideological tensions in the ESL classrooms. Journal of Language, Culture, and Curriculum, 6(2), 143-156.

Clarke, M. (2008). Language teacher identities: Co-constructing discourse and community. Clevedon: Multilingual Matters.

Crozet, C., \& Liddicoat, A. J. (1999). The challenge of intercultural language teaching: Engaging with culture in the classroom. In J. LoBianco, A. J. Liddicoat, \& C. Crozet (Eds.), Striving for the third place: Intercultural competence through language education (s. 113-126). Canberra: Language Australia.

Duff, P., \& Uchida, Y. (1997). The negotiations of teachers' sociocultural identities and practices in postsecondary EFL classrooms. TESOL Quarterly, 31(3), 451-486. 
Eco, U. (1979). The role of the reader. Bloomington: Indiana University Press.

Eco, U. (2010). Lector in fabula. Praha: Academia.

Foucault, M. (1972). The discourse on language. In The archaeology of knowledge (s. 215-237). New York: Pantheon.

Gee, J. P. (2011). An introduction to discourse analysis. New York: Routledge.

Gray, J. (2002). The global coursebook in English language teaching. In D. Block \& D. Cameron (Eds.), Globalization and language teaching (s. 151-167). London: Routledge.

Gray, J. (2010). The branding of English and the culture of the new capitalism: Representations of the world of work in English language textbooks. Applied Linguistics, 31(5), 714-733.

Hartman, P. L., \& Judd, E. L. (1978). Sexism and TESOL materials. TESOL Quarterly, 12(4), 383393.

Hodge, R., \& Kress, G. (1993). Language as ideology. New York: Routledge.

Huckin, T. N. (1997). Critical discourse analysis. In T. Miller (Ed.), Functional approaches to written text: Classroom applications (s. 78-92). Washington D. C.: United States Information Agency.

Hyland, K. (2012). Disciplinary identities. Cambridge: Cambridge University Press.

Jenkins, J. (2007). English as a lingua franca: Attitude and identity. Oxford: Oxford University Press.

Jörgensen, M., \& Phillips, L. (2002). Discourse analysis as theory and method. London: Sage Publications.

Koláčková, L. (2011). Kritéria, podle nichž učitelé AJ vybírají učebnice. CASALC Review, 1(1), 30-36.

Kostková, K. (2012). Rozvoj interkulturní komunikační kompetence. Brno: Masarykova Univerzita.

Kramsch, C. (1993). Context and culture in language teaching. Oxford: Oxford University Press.

Kramsch, C. (2014). Teaching foreign languages in an era of globalisation: Introduction. The Modern Language Journal, 98(1), 296-311.

Krippendorf, K. (2013). Content analysis: An introduction to its methodology. Los Angeles: Sage.

Lee, I. (2011). Teaching how to discriminate: Globalization, prejudice, and textbooks. Teacher Education Quarterly, 38(1), 47-63.

Luke, A. (1989). Open and closed texts: The ideological/semantic analysis of textbook narratives. Journal of Pragmatics, 13(1), 53-80.

Markus, H., \& Nurius, P. (1986). Possible selves. American Psychologist, 41(9), 954-969.

Matsuda, A. (2002). Representation of users and uses of English in beginning Japanese EFL textbooks. JALT Journal, 24(2), 182-200.

Melliti, M. (2013). Global content in global coursebooks: The way issues of inappropriacy, inclusivity, and connectedness are treated in Headway Intermediate. SAGE Open, 3(4), 1-12.

Norton, B. (2000). Identity and language learning: Gender, ethnicity and educational change. London: Pearson Education Limited.

Norton, B. (2001). Non-participation, imagined communities and the language classroom. In M. Breen (Ed.), Learner contributions to language learning: New directions in research (s. 159-171). London: Longman/Pearson Education.

Phillipson, R. (1992). Linguistic imperialism. Oxford: Oxford University Press.

Porreca, K. L. (1984). Sexism in current ESL textbooks. TESOL Quarterly, 18(4), 705-724. 
Prabhu, N.S. (1992). The dynamics of the language lesson. TESOL Quarterly, 26(2), 225-241.

Průcha, J. (1998). Učebnice: teorie a analýzy edukačního média. Brno: Paido.

Průcha, J. (2001). Multikulturní výchova: teorie - praxe - výzkum. Praha: ISV.

Průcha, J. (2004. Interkulturní psychologie. Praha: Portál.

Radimský, J. (2001). Genderové stereotypy v českých učebnicích. Gender, rovné příležitosti, výzkum, 2(1-2), 7-8.

Rámcový vzdělávací program pro gymnázia. (2007) Praha: VUP. Dostupné z http://www.msmt. cz/vzdelavani/skolstvi-v-cr/skolskareforma/ramcove-vzdelavaci-programy

Renzetti, C. M., \& Curran, D. J. (2003). Ženy, muži a společnost. Praha: Karolinum.

Schumann, J. H. (1981). The sociology of second language acquisition. Language Learning, 26(7), 1-18.

Shardakova, M., \& Pavlenko, A. (2004). Identity options in Russian textbooks. Journal of Language, Identity and Education, 3(1), 25-46.

Společný evropský referenční rámec pro jazyky. (2012). Olomouc: Univerzita Palackého. Dostupné z http://www.msmt.cz/mezinarodni-vztahy/spolecny-evropsky-referencni-ramec-projazyky

Stephens, K. (1990). The world of John and Mary Smith: A study of Quirk and Greenbaum's University Grammar of English. CLE Working Papers 1(1), 91-107.

Sunderland, J. (1992). Gender in the EFL classroom. ELT Journal, 46(1), 81-91.

Šafr, J. (2008). Images of social classes and strata. In J. Šafr \& J. Hauberer (Eds.), Social distances and stratification: Social space in the Czech Republic (s. 67-76). Praha: Sociologický ústav AV ČR.

Švec, Š., et al. (1998). Metodológia vied o výchove. Bratislava: Iris.

Tomlinson, B., \& Masuhara, H. (2013). Survey review: Adult coursebooks. ELT Journal, 67(2), 233-249.

Warschauer, M. (2000). The changing global economy and the future of English teaching. TESOL Quarterly, 34(3), 511-535.

West, C. (1992). A matter of life and death. October, 61(summer), 20-23. Dostupné z http:// academiccommons.columbia.edu/catalog/ac\%3A157361

Wodak, R., \& Meyer, M. (Eds.). (2009). Methods of critical discourse analysis. London: Sage.

\section{Analyzované učebnice:}

Peters, S., \& Gráf, T. (2001). Time to talk 1. Praha: Polyglot.

Peters, S., \& Gráf, T. (2002). Time to talk 2. Praha: Polyglot.

Peters, S., \& Gráf, T. (2003). Time to talk 3. Praha: Polyglot.

Peters, S., \& Gráf, T. (2004). Time to talk 4. Praha: Polyglot.

\section{Autorka}

Mgr. Jana Kubrická, Ph.D., Masarykova Univerzita, Centrum jazykového vzdělávání, Komenského nám. 2, 60200 Brno, e-mail: kubricka@fsps.muni.cz 


\title{
"Time to Talk" or Who owns English in a Czech EFL textbook
}

\begin{abstract}
In this paper we deal with identities portrayed in a Czech textbook of English as a foreign language Time to Talk. The main goal of the paper is to describe various aspects of the portrayed identities and the ways of restricting interpretation of cultural content in texts and tasks. Firstly, we discuss the concept of identity in foreign language teaching and identity research in foreign language textbooks. We employ the method of content analysis, critical discourse analysis and the concept of open and closed texts to capture the image of the target language community depicted in the textbook. In an analysis of texts, illustrations and associated tasks we demonstrate that the textbook reflects the current intercultural discourse, which involves the presentation and confrontation of diverse cultures, however, we point to the dominant role of British culture and the authority of British native speakers. The portrayed characters are members of the ethnic majority, middle to upper social class, and they are often depicted in a gender-stereotypical manner. Nevertheless, there is an apparent influence of the discourse of cultural incorporation, which means that formerly underrepresented groups are granted space in the textbook.
\end{abstract}

Keywords: foreign language textbooks, identity, native speaker, multicultural education, critical discourse analysis, open and closed text

Janíková, V., Píšová, M., \& Hanušová, S. (Eds.). (2014). Aktuální témata výzkumu učení a vyučování cizím jazykům III. Brno: Masarykova univerzita.

Předložená odborná kniha je př́spěvkem k teoretickému i empirickému bádání $v$ oblasti učení a vyučování cizích jazyků v České republice. Svými obsahy přispívá k obnovování kontinuální reflexe vývoje nejvlivnějších trendů v zahraniční i české didaktice cizích jazyků se zřetelem k metodologii jejího výzkumu v těsném propojení s vývojem výzkumných metod referenčních disciplín. Díky výrazné interdisciplinaritě didaktiky cizích jazyků je její výzkumné pole velmi široké, což se odráží i ve struktuře publikace. V úvodní kapitole je nastíněn kvalitativní výzkum v didaktice cizích jazyků s těžištěm položeným na přístup etnografický a biografický. Následující kapitoly jsou rozčleněny do pěti tematických okruhů, které jsou zaměřeny na (1) procesy vyučování cizímu jazyku (2) procesy učení se cizímu jazyku, (3) mnohojazyčnost (procesy učení se více jazykům v kontextu rozvoje individuální mnohojazyčnosti), (4) cizojazyčnou komunikační kompetenci a (5) metody a organizaci výuky. 